\title{
Risk burden, participation in early childhood education and care, and child outcomes
}

\author{
Nicholas Biddle \\ Heather Crawford \\ Australian National University
}

Robyn Seth-Purdie

Griffith University

\begin{abstract}
IN 2008, AUSTRALIAN COMMONWEALTH and state and territory governments signed a National Partnership Agreement on Early Childhood Education, committing to provide universal access to quality early childhood education in the year before full-time schooling. The agreement noted that early childhood is a critical development period and quality early childhood education programs particularly benefit children at risk of poorer outcomes. Using the Longitudinal Study of Australian Children, we show that for children aged four to five years in 2008 , baseline risk factors were significantly associated with a range of poorer outcomes in the early school years and these associations were not offset by participation in a preschool program or attendance at day care without a preschool program. These results serve as a benchmark for the success of subsequent initiatives to provide children with universal access to quality preschool programs.
\end{abstract}

\section{Introduction}

In 2008, the Australian Commonwealth and state and territory governments signed a National Partnership Agreement on Early Childhood Education (the 'National Partnership Agreement'), which heralded reforms to the provision of early childhood education (COAG, 2009). In Australia, use of formal childcare services has increased over recent decades due to increasing maternal labour force participation (Hayes, Weston, Qu \& Gray, 2010; PwC, 2012). This trend, along with greater awareness that early childhood is a critical developmental period (Shonkoff \& Marshall, 2000), has led policy-makers to focus on children's experiences in early childhood education and care, with the aim of promoting healthy development and learning through early childhood education programs (Elliott, 2006; Oberklaid, Baird, Blair, Melhuish \& Hall, 2013; PwC, 2012; PC, 2014). In the National Partnership Agreement, Australian governments committed to provide every child with access to quality early childhood education for 15 hours a week, 40 weeks a year, in the year before starting full-time schooling (COAG, 2009).

The early childhood sector in Australia is complex, with the provision of preschool programs varying according to provider type (government, community or private), setting (stand alone, schools, childcare centres), aspects of quality, funding and fees (Urbis Social Policy, 2011, pp. 90-92).
The challenge of delivering coordinated services to vulnerable families, given the fragmented nature of early childhood services, was one rationale for a national approach (COAG, 2009).

The positive association between participation in preschool education for children aged three to five years and child outcomes 'is unequivocal', according to the Productivity Commission's inquiry report, Childcare and Early Childhood Learning, which cites international and Australian studies (PC, 2014, pp. 149-158). High-quality early childhood education is considered to promote optimal development for participating children (PC, 2014, p. 151) and to be a potentially effective form of early intervention for developmentally vulnerable children (Harrison, Goldfeld, Metcalfe \& Moore, 2012; Magnuson, Ruhm \& Waldfogel, 2007; PC, 2014, pp. 154-158; Urbis Social Policy, 2011). Developmental vulnerability can lead to educational underachievement, a potential cause of Australia's stagnating performance in international tests at primary and secondary levels (Zyngier, 2012), and a range of negative lifetime outcomes (e.g. Shonkoff, Richter, van der Gaag \& Bhutta, 2012). The importance of high-quality preschool education and care for disadvantaged children in particular is a focus of the National Partnership Agreement (COAG, 2009) and is highlighted in the Productivity Commission's report (PC, 2014). 
The literature identifies various risk factors for developmental vulnerability. These include low birth weight (Mallik \& Spiker, 2004); poorly educated or unemployed parents (Coley \& Lombardi, 2012; Gray \& Baxter, 2012; Kalil, 2009; Sameroff, 1998); family poverty (Pordes Bowers, Strelitz, Allen \& Donkin, 2012); housing instability (Lewis, 2006; Taylor \& Edwards, 2012); overcrowding (Blake, Kellerson \& Simic, 2007); unresponsive or insensitive parenting (Linver, Brooks-Gunn \& Kohen, 2002; Pettit, Bates \& Dodge, 1997; Sameroff, 1998; Smart, Sanson, Baxter, Edwards \& Hayes, 2008); unstimulating or impoverished surroundings (Sameroff, 1998); and exposure to conflict or abuse (Koenen, Moffitt, Caspi, Taylor \& Purcell, 2003; Lupien, McEwen, Gunnar \& Heim, 2009). While exposure to a single risk factor seems to have only a small effect on outcomes, exposure to multiple risk factors - that is, a higher level of risk burden-distinguishes the high-risk child from other children (Fergusson \& Horwood, 2003). In Australia in 2015, 22 per cent of children were developmentally vulnerable on at least one domain; this percentage was higher among boys, Indigenous children, those in very remote areas and those in areas of greater socioeconomic disadvantage (Australian Government, 2015).

The presence of risk factors has been found to be associated with a lower likelihood of participation in preschool or day care (Baxter \& Hand, 2013). The need to account for family and household factors in analysing the relationship between participation in preschool education or care and child outcomes has also been noted (PC, 2014, pp. 152-153). To understand the relative importance of risk factors on the one hand and participation in preschool education and care on the other, analysis of child outcomes needs to include both of these dimensions.

Our analysis focused on children four to five years old who had not yet started full-time schooling and their outcomes two years later. We examined the relationship between children's risk factors and whether they mainly participated in a preschool program (hereafter referred to as 'preschool') or attended day care without a preschool program; the relationship between children's risk burden and their outcomes two years later; and whether children's participation in preschool or day care without a preschool program moderated the relationship between risk factors and outcomes.

\section{Data and methods}

Our study drew on the Longitudinal Study of Australian Children (LSAC). LSAC, the first national survey to collect data, tracking Australian children over time, aims to provide evidence about children's developmental pathways and factors affecting their outcomes. LSAC has ethics approval from the Australian Institute of Family Studies Ethics Committee, which is registered with the Australian Health Ethics Committee, a subcommittee of the National Health and Medical Research Council. Caregivers gave written informed consent to the survey, including on behalf of the study children (Zubrick, Taylor \& Christensen, 2015). The sample was selected from the Medicare database and was designed to be a nationally representative sample of Australian infants and four- to five-year-olds (Soloff, Lawrence \& Johnstone, 2005). Main data collection methods included computer-assisted face-to-face interviews and self-completion questionnaires. Information relating to the study child was obtained from parents, teachers and interviewer observation. LSAC is underpinned by an ecological model of development, whereby children's interactions with their social environments, including family, school and community, are seen as major influences on their development (AIFS, 2015).

LSAC was constructed around two cohorts of children-the Baby ('B') cohort (born March 2003-February 2004) and the Kindergarten ('K') cohort (born March 1999-February 2000). LSAC contains information about a much broader range of child outcomes than previous studies, including social, emotional and cognitive outcomes (Sanson et al., 2002). Our analysis focuses on the B cohort of approximately 5100 children aged from three to 19 months when LSAC began in 2004. When Wave 3 was conducted in 2008, 86 per cent (4400) of these children remained in the study, and at Wave 4, 83 per cent (4200) remained (AIFS, 2014). Our analysis used measures of participation in preschool and attendance at day care without a preschool program and risk factors from Wave 3, conducted in 2008 when the children in the B cohort were four to five years old, and outcome measures from Wave 4, conducted in 2010 when the children were six to seven years old.

\section{Developmental risk factors included in LSAC}

Information about developmental risk factors is an important component of LSAC, given its objective of contributing to research into children's developmental pathways.

Table 1 lists the risk factors included in our analysis. Population weights were applied to calculate the prevalence of each risk factor among the Australian population of children four to five years old, not just within the sample.

Table 1 demonstrates significant variation in the prevalence of the 25 risk factors. About 39 per cent of primary carers of these children were not employed. There is a similarly large prevalence of low education among primary carers (32 per cent), the child not being breastfed at one month or low birthweight (25 per cent), a low reading environment (24 per cent) and income poverty (24 per cent). Risk factors with a low prevalence were parental substance use (2 per cent), having a teenage mother (3 per cent), housing stress (4 per cent) and parental instability (5 per cent).

The final line of Table 1 shows that each child had, on average, four risk factors. Overall, approximately 92 per cent of Australian children who were four to five years old in 2008 had at least one of these risk factors. However, there is considerable variation across the sample (Figure 1, on page 53). 
Table 1. Risk factors for developmental vulnerability, LSAC B cohort, Wave 3, 2008

\begin{tabular}{|c|c|c|}
\hline Risk factor & Associated variables & $\begin{array}{l}\text { Percentage of } \\
\text { population }\end{array}$ \\
\hline Poverty & $\begin{array}{l}\text { Equivalised household income below } 60 \% \text { of median; } \\
\text { experienced a financial hardship in previous } 12 \text { months; } \\
\text { or self-identifies family as being poor or very poor }\end{array}$ & 22 \\
\hline Housing instability & Study child moved twice or more in previous two years & 6 \\
\hline Housing stress & $\begin{array}{l}\text { More than two persons per bedroom; } \\
\text { or unmet need for housing services in past } 12 \text { months }\end{array}$ & 4 \\
\hline Competition for parenting time & $\begin{array}{l}\text { Four or more children in the household; } \\
\text { study child has same-age siblings; } \\
\text { or primary carer receives carer allowance }\end{array}$ & 18 \\
\hline Neighbourhood disadvantage & Study child lives in most disadvantaged $20 \%$ of neighbourhoods & 15 \\
\hline Low accessibility & $\begin{array}{l}\text { Study child lives in a moderately accessible or remote/very } \\
\text { remote area }\end{array}$ & 18 \\
\hline Difficult temperament & $\begin{array}{l}\text { Study child is more or much more difficult than average to } \\
\text { get on with }\end{array}$ & 7 \\
\hline Biomedical risk factors & Study child has a long-term medical condition or disability & 10 \\
\hline Early childhood risk factors & $\begin{array}{l}\text { Study child was not breastfed at one month; } \\
\text { or study child had a birth weight of less than } 2500 \text { grams }\end{array}$ & 25 \\
\hline High TV watching & Child watches four or more hours of TV per day & 10 \\
\hline Sole parent & Primary carer is the only parent present in the household & 14 \\
\hline Low other parent employment & Other parent is present in the household but not employed & 6 \\
\hline Low primary carer employment & Primary carer is not employed & 39 \\
\hline High primary carer employment & Primary carer works 40 hours or more per week & 10 \\
\hline Teenage mother & $\begin{array}{l}\text { Mother was less than } 20 \text { years old in Wave } 1 \\
\text { (when child was 0/1) }\end{array}$ & 3 \\
\hline Low primary carer education & $\begin{array}{l}\text { Primary carer has not completed Year } 12 \text { and does not have a } \\
\text { Certificate III or higher }\end{array}$ & 32 \\
\hline Potential language difficulties & $\begin{array}{l}\text { Primary carer speaks a language other than English at home } \\
\text { and speaks English not well or not at all; } \\
\text { or study child speaks a language other than English at home }\end{array}$ & 13 \\
\hline Parental psychological distress & $\begin{array}{l}\text { Primary carer had a high value on the K-6 psychological } \\
\text { distress scale }\end{array}$ & 14 \\
\hline $\begin{array}{l}\text { Primary carer or other parent in } \\
\text { poor health }\end{array}$ & $\begin{array}{l}\text { Primary carer or other parent has a long-term medical condition } \\
\text { or disability }\end{array}$ & 13 \\
\hline Indigenous child & Study child is identified as being Indigenous & 5 \\
\hline Poor parenting skills & $\begin{array}{l}\text { Primary carer reports low parental warmth; } \\
\text { or primary carer reports high parental hostility }\end{array}$ & 19 \\
\hline Low reading & $\begin{array}{l}\text { Study child was read to by parents less than three days } \\
\text { in past week }\end{array}$ & 24 \\
\hline Parental conflict & $\begin{array}{l}\text { Primary carer reports anger or hostility between themselves } \\
\text { and their partner }\end{array}$ & 11 \\
\hline Parental substance use & $\begin{array}{l}\text { In the past year, someone in the household had an alcohol } \\
\text { or drug problem }\end{array}$ & 2 \\
\hline Parental instability & $\begin{array}{l}\text { At least one of the child's primary carer or other parent changed } \\
\text { between Wave } 2 \text { and Wave } 3\end{array}$ & 5 \\
\hline \multicolumn{2}{|l|}{ Average number of risk factors } & 4 \\
\hline
\end{tabular}

Source: Population-weighted estimates based on the LSAC B cohort, Wave 3, sample of 4400 children aged four to five years old in 2008. 


\section{LSAC information about children's participation in preschool and attendance at day care without a preschool program}

The Wave 3 LSAC questionnaire included questions about children's education and care settings and programs, to distinguish between different combinations of settings and programs (AIFS, 2016). We draw on information derived from these questions. The first question is:

Does the study child currently go to a school, kindergarten, preschool or a long day care centre?

If the answer is yes, the next relevant question is:

(Thinking about the arrangement the child uses for the most hours per week, or has been attending the longest, if two programs attended for an equal number of hours) Is it located in a school?

If a child attends an education or care program located in a school, the next question is:

What class or program does the study child attend? (Responses are assigned to categories: Year 1 [Grade 1]; pre-Year 1 program; Preschool/kindergarten; Long day care centre [including an early learning program]; other).

Alternatively, if a child attends an education or care program not located in a school, the next question is:

Which of the following best describes where the study child goes? (Response options offered: Preschool/ kindergarten-only centre; Preschool/kindergarten in a long day care centre; mobile preschool; long day care centre; other).

The information obtained from these questions enables us to distinguish between children attending a preschool program (whatever the setting) and those attending a day care centre without a preschool program. Where children are attending both of these, they are assigned to a category according to the arrangement in which they spent the most hours (the 'main' arrangement) (see Figure 2).

About half of the children were mainly attending preschool (Figure 2). This comprised 45 per cent attending preschool only and 5 per cent attending both preschool and (for fewer hours) day care without a preschool program. Just over a quarter of the children mainly attended day care without a preschool program. Most of these were attending day care without a preschool program only, with just 3 per cent of children attending day care without a preschool program and (for fewer hours) a preschool program.

About 6 per cent of the population of children were not attending preschool and not attending day care. The remaining children, who were participating in Year 1 in school, a pre-Year 1 program, or another form of care, were excluded from the analysis, as there was no comparable information for them on the prevalence of risk factors before commencing full-time schooling. The analysis therefore covers those children in the categories to the left of the dotted line in Figure 2.

\section{Child development outcomes}

LSAC covers multiple domains of children's development, including physical health, social and emotional functioning, cognitive functioning and educational achievement (Wake et al., 2008). We selected indicators of children's development in the areas of social and emotional functioning, academic achievement and school adjustment as our outcome measures.

Table 2 presents five measures of child development outcomes based on the data from Wave 4 of LSAC, conducted in 2010 (when the children in the B cohort were six to seven years old), and gives the prevalence of poorer outcomes among this group (excluding those who were attending full-time schooling in Wave 3).

The Academic Rating Scales are measures of school performance in literacy and numeracy (Rothman, 2009). The Strengths and Difficulties Questionnaire (SDQ) (Goodman, 1997) assesses peer problems, conduct problems, hyperactivity, emotional problems and prosocial behaviours for children aged three-17 years. Higher scores on the subscales for hyperactivity, emotional problems, peer problems and conduct problems reflect more problematic behaviour. The scores for these four scales are added together to give a total difficulties score.

Table 2. Prevalence of poor child outcomes, LSAC B cohort (excluding children attending full-time school in Wave 3), Wave 4

\begin{tabular}{|c|c|}
\hline Characteristic & $\begin{array}{l}\text { Percentage } \\
\text { of sample }\end{array}$ \\
\hline $\begin{array}{l}\text { Low achievement-Teacher rates child's } \\
\text { academic skills, compared to other } \\
\text { children of the same grade level, as } \\
\text { below average or far below average. }\end{array}$ & 19 \\
\hline $\begin{array}{l}\text { Low maths-Child scores one standard } \\
\text { deviation below mean value for Academic } \\
\text { Rating Scale of Mathematical thinking } \\
\text { (teacher rating). }\end{array}$ & 19 \\
\hline $\begin{array}{l}\text { Low literacy-Child scores one standard } \\
\text { deviation below mean value for Academic } \\
\text { Rating Scale of Language and Literacy } \\
\text { (teacher rating). }\end{array}$ & 18 \\
\hline $\begin{array}{l}\text { Poor SDQ (Strengths and Difficulties } \\
\text { Questionnaire) ranking-Child ranks } \\
\text { relatively poorly (12 and above) on } \\
\text { total difficulties score of the SDQ } \\
\text { (parent/carer rating). }\end{array}$ & 24 \\
\hline $\begin{array}{l}\text { Poor school adjustment-Child ranks } \\
\text { relatively low (score } 1.8 \text { or higher) on } \\
\text { self-assessed school adjustment index } \\
\text { (child rating). }\end{array}$ & 24 \\
\hline
\end{tabular}

Source: Customised calculations using Wave 4 of LSAC. 


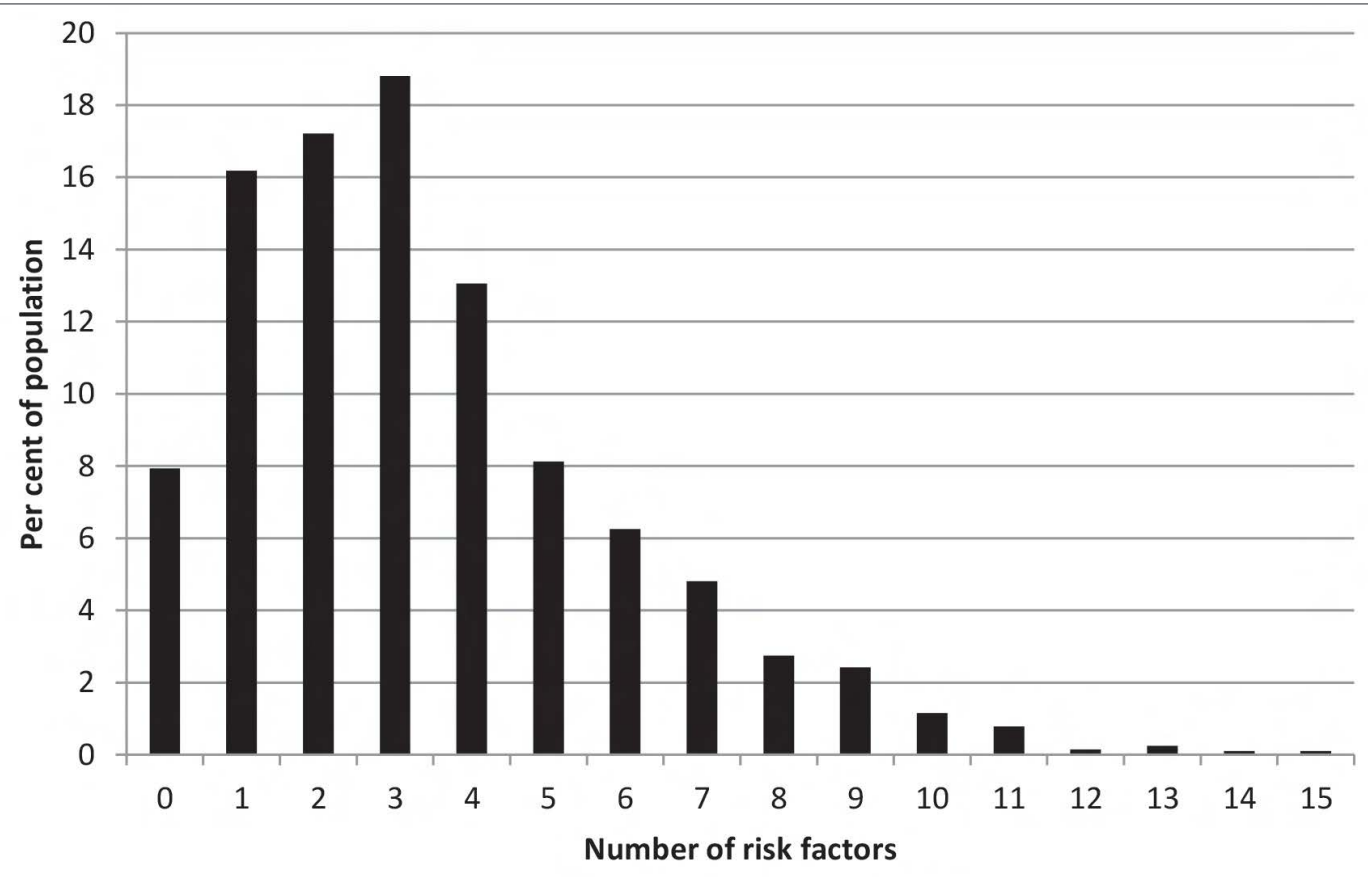

Source: Population-weighted estimates based on the LSAC B cohort, Wave 3, sample of 4400 children aged four to five years old in 2008. Figure 1. Risk burden, LSAC B cohort, Wave 3, 2008

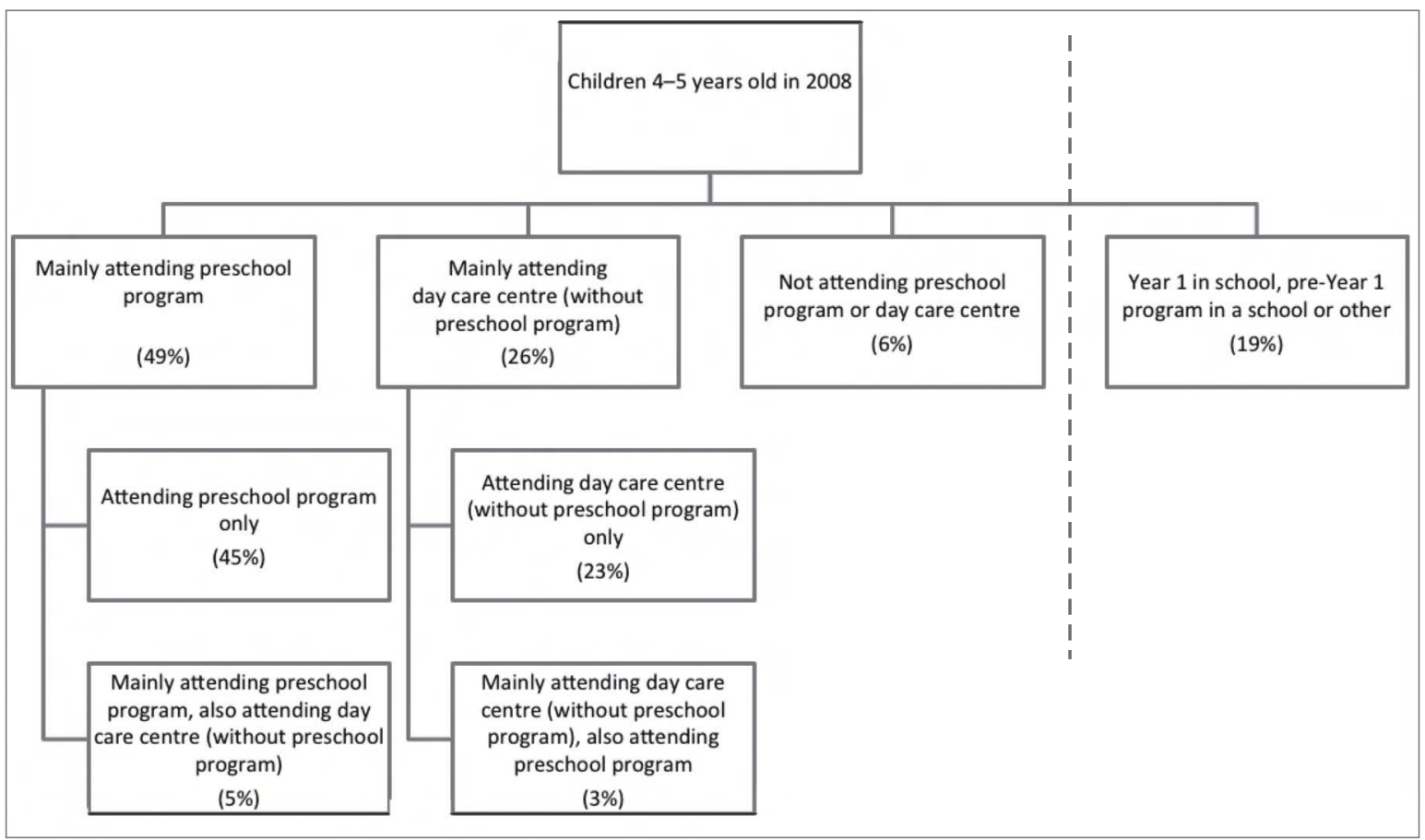

Source: Population-weighted estimates based on the LSAC B cohort, Wave 3, sample of 4400 children aged four to five years old in 2008.

Figure 2. Patterns of participation in preschool and day care-LSAC B cohort, Wave 3, 2008 


\section{Results}

\section{Relationship between risk burden and participation in early childhood education}

Our analysis showed that as the number of risks increases, the probability of attending preschool or day care without a preschool program decreases. A linear prediction of the relationship between risk burden and preschool or day care showed that, on average, each additional risk factor is associated with a statistically significant decrease in the probability of attending preschool equal to -0.019 . The relationship between risk burden and attendance at day care without a preschool program was somewhat weaker (with each additional risk factor being associated with a decrease in the probability of attending day care equal to -0.009 ) but still significant.

Table 3 looks at the relationship between specific risk factors and participation in preschool or day care without a preschool program. Results are generated from a multivariate analysis undertaken using the Probit model, a type of regression used to model the probability of a particular outcome occurring using binary outcome variables (Greene, 2003). The two outcome variables were: whether the child was attending preschool and whether the child was attending day care without a preschool program. The results presented are marginal effects. The marginal effect represents the difference in the probability of attending for a child with that characteristic, compared to a 'base case' individual, while holding all other variables constant. The base case individual is female, 57 months old (the average for the dataset), and has no risk factors.

Where risk factors are significantly associated with both preschool and day care attendance, the association of the risk factor with one is always in the opposite direction to its association with the other. It would appear, therefore, that different factors influenced parents' choice of preschool or day care for their child. For example, there is a positive association between the primary carer working long hours and a child's attendance at day care, but a negative association between the primary carer working long hours and a child's attendance at preschool. Families with a primary carer-usually the mother-working longer hours would have been more likely to require day care as at least one form of care for their children, even if such a service did not offer a preschool program. Previous research shows that convenience was highly rated as a reason parents chose multiple childcare arrangements (including informal care), along with perceived benefits for children of experiencing a centre-based environment (Bowes et al., 2003; Bowes et al., 2004).

Two risk factors were associated with a higher probability of preschool attendance. First, greater neighbourhood disadvantage was associated with a greater likelihood of attending preschool. The second factor was the primary carer not being employed.
Table 3. Marginal effect of explanatory variables on the probability of attending preschool or a day care centre without a preschool program, as the main type of arrangement attended, LSAC B cohort (excluding children attending full-time school in wave 3), Wave 4

\begin{tabular}{|c|c|c|}
\hline Explanatory variables & $\begin{array}{l}\text { Preschool } \\
\text { program }\end{array}$ & $\begin{array}{l}\text { Day care } \\
\text { without a } \\
\text { preschool } \\
\text { program }\end{array}$ \\
\hline Study child is male & -0.015 & 0.014 \\
\hline Age of study child (months) & $0.018 * * *$ & $-0.014 * * *$ \\
\hline Poverty & -0.002 & 0.030 \\
\hline Housing instability & $-0.089 * *$ & 0.023 \\
\hline Housing stress & -0.086 & -0.101 \\
\hline $\begin{array}{l}\text { Competition for } \\
\text { parenting time }\end{array}$ & 0.016 & $-0.072 * * *$ \\
\hline Neighbourhood disadvantage & $0.076 * * *$ & $-0.073 * *$ \\
\hline Low accessibility & 0.007 & -0.041 \\
\hline Difficult temperament & -0.033 & $0.147 * * *$ \\
\hline Biomedical risk factors & 0.041 & $-0.060 *$ \\
\hline Early childhood risk factors & -0.027 & 0.038 \\
\hline High TV watching & -0.011 & $-0.088 * *$ \\
\hline Sole parent & $-0.108 * * *$ & $0.168 * * *$ \\
\hline $\begin{array}{l}\text { Low other parent } \\
\text { employment }\end{array}$ & $-0.121 * *$ & $0.091 *$ \\
\hline $\begin{array}{l}\text { Low primary carer } \\
\text { employment }\end{array}$ & $0.084 * * *$ & $-0.200 * * *$ \\
\hline $\begin{array}{l}\text { High primary carer } \\
\text { employment }\end{array}$ & $-0.102 * * *$ & $0.127 * * *$ \\
\hline Teenage mother & -0.017 & -0.054 \\
\hline Low primary carer education & $-0.055 * *$ & 0.017 \\
\hline Potential language difficulties & $-0.077 * *$ & 0.011 \\
\hline $\begin{array}{l}\text { Parental psychological } \\
\text { distress }\end{array}$ & -0.009 & -0.007 \\
\hline $\begin{array}{l}\text { Primary carer or other parent } \\
\text { in poor health }\end{array}$ & -0.019 & 0.011 \\
\hline Indigenous child & $-0.152 * * *$ & -0.001 \\
\hline Poor parenting skills & 0.030 & 0.014 \\
\hline Low reading & $-0.129 * * *$ & $0.081 * * *$ \\
\hline Parental conflict & 0.042 & $-0.053 *$ \\
\hline Parental substance use & -0.017 & -0.092 \\
\hline Parental instability & -0.063 & 0.021 \\
\hline Probability of the base case & 0.715 & 0.411 \\
\hline Pseudo R-squared & 0.0536 & 0.0678 \\
\hline Number of observations & 2702 & 2703 \\
\hline
\end{tabular}

Note: The base case individual is female, 57 months old, and has none of the included risk factors. Variables for which the coefficient is statistically significant at the 1 per cent level of significance are labelled ***; those statistically significant at the 5 per cent level of significance only are labelled ${ }^{*}$; ; and those statistically significant at the 10 per cent level of significance only are labelled *.

Source: Customised calculations using Wave 3 of LSAC. 
At least part of the explanation for this may be that primary carers who are not working (whether by choice or necessity) are more likely to be available to drop off and pick up children from dedicated preschool services covering six hours of preschool per day.

Several risk factors were associated with a lower probability of preschool participation: housing instability; sole parent family; other parent in a couple family not employed; low primary carer education; potential language difficulties; Indigenous child; and child seldom read to by parents. Given that income poverty was controlled for (and not found to be significant), it seems that financial constraints are not the only barriers for these groups. Rather, these families may not see preschool education as being relevant to them or meeting their needs.

The risk factors that were positively associated with attendance at day care were different from those positively associated with preschool participation. These were: difficult temperament; sole parent; primary carer working long hours; and child seldom read to by parents. Negative associations were with competition for parenting time (family with over four children or subject child with same-age sibling); disadvantaged neighbourhood; high TV watching (four or more hours per day); and primary carer not employed.

\section{Association between risk factors and child development outcomes}

Figure 3 on page 56 illustrates the strong relationship between the presence of one or more risk factors among four- to fiveyear-olds and most of the negative child outcomes among these children two years later as six- to seven-year-olds. Results are presented (separately for each outcome) as the proportion of the (weighted) sample with that outcome, conditional on the number of risk factors. The bounds around the estimates represent 95 per cent confidence intervals.

For the first four of the five outcomes, negative child outcomes tend to be more likely to be reported for those with a higher number of risk factors. There does not, however, appear to be a linear relationship between risk factors and poor school adjustment.

So far, our analysis has shown that children with a higher risk burden are less likely to attend either preschool or day care without a preschool program, and that those with a higher risk burden are more likely to have poorer outcomes in the early school years.

The last analysis presented here examines whether attendance at preschool or day care moderates the association between developmental risk factors and children's outcomes in the early school years. We do this through a modelling approach with five dependent variables (representing each of the five child outcomes), estimated separately using the same set of explanatory variables in each case. Results are again presented as marginal effects (see Table 4).
There were significant associations between risk factors and child outcomes, but not between attendance at preschool or day care and child outcomes (Table 4). This illustrates that developmental risks are more important factors in child outcomes than children's attendance at preschool or day care. Participation in preschool or in day care without a preschool program did not moderate the negative association between risk factors and children's outcomes. In fact, longer hours of attendance were significantly associated with poorer outcomes: a greater probability of low achievement and poor SDQ rating for long hours in day care (without a preschool program) and a greater probability of poor school adjustment for long hours in preschool. These findings are in line with findings from previous research linking lower literacy scores and lower liking of school among those who attended long hours of care or education in the year before school (Bowes, Harrison, Sweller, Taylor \& Neilsen-Hewett, 2009).

Apart from gender, three risk factors had a significant association with three or more of the child outcomes: poverty, biomedical risk factors and low parental education. These three variables, being significantly associated with multiple poor child outcomes, seem prime candidates for particular attention from governments and other service providers.

\section{Summary and conclusion}

Participation in preschool or day care-if well targeted and of sufficiently high quality-can benefit children from at-risk groups (Harrison et al., 2012). We did not, however, find evidence for this for Australian children aged four to five years in 2008. Not only were the highest levels of participation in preschool or day care found among children with the lowest risk burdens, but participation in preschool or day care did not offset significant associations between risk factors and poor child outcomes in the early school years.

Our results illustrate the value of a longitudinal dimension, showing that the presence of risk factors at the time the children were attending preschool or day care is associated with poorer outcomes two years later when the children were in the early years of school. Our study also has some limitations. First, LSAC does not cover all the risk factors identified in the literature, and some exposure to risk factors may not be captured because it occurs between the points in time when data is collected. Another limitation is that the analysis does not account for the time spent in formal or informal child care (both elapsed time and hours per week) before the age of four years. Evidence of the association between child outcomes and attendance at child care for younger children, particularly those attending for longer hours per week, is mixed (PC, 2014).

Most benefits of preschool or day care demonstrated in randomised controlled trials have come from high-quality programs (Heckman, 2013). 


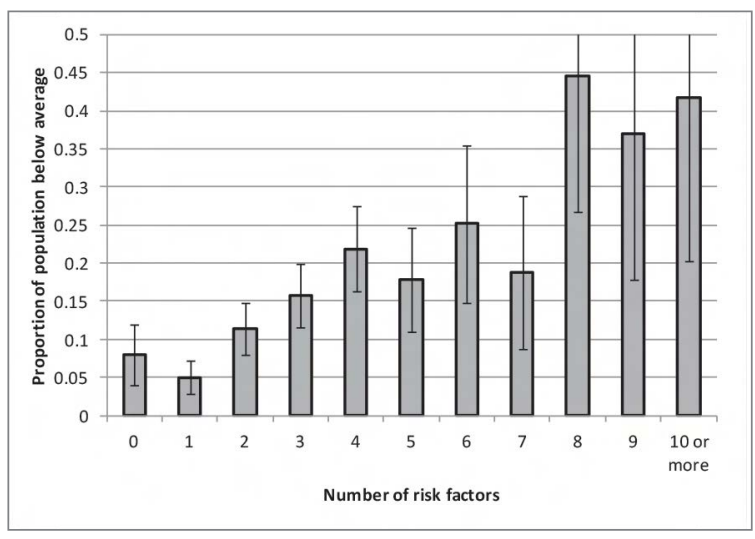

Figure 3a. Low achievement

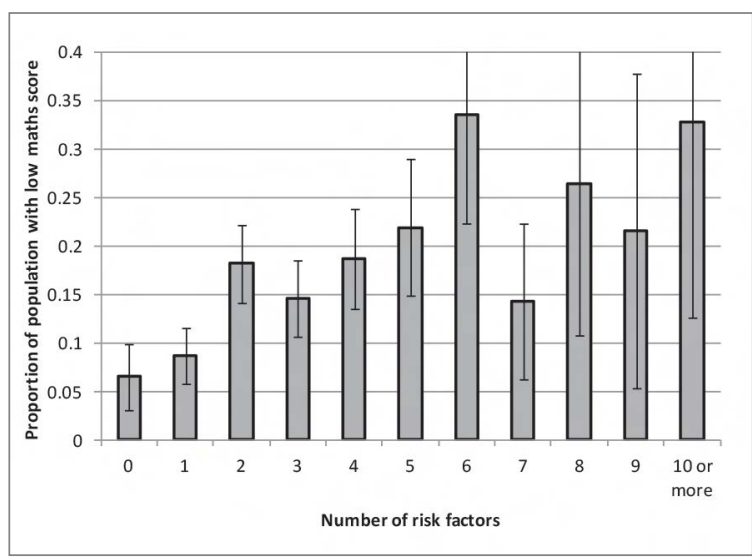

Figure 3b. Low numeracy

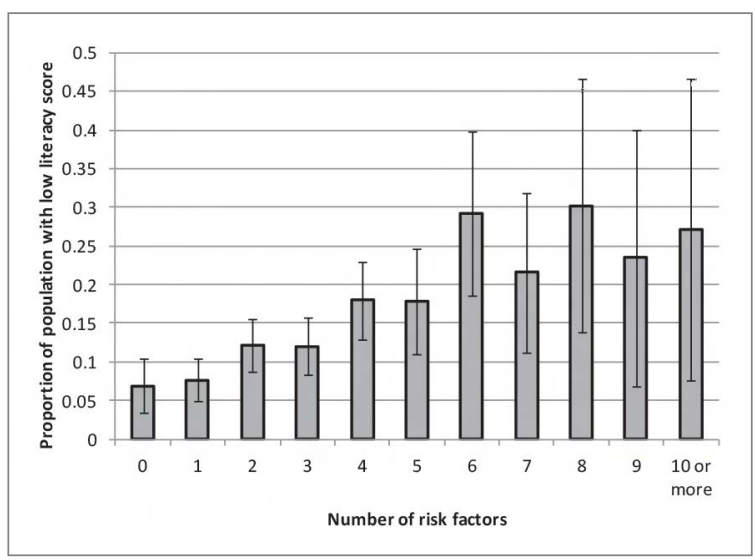

Figure 3c. Low literacy

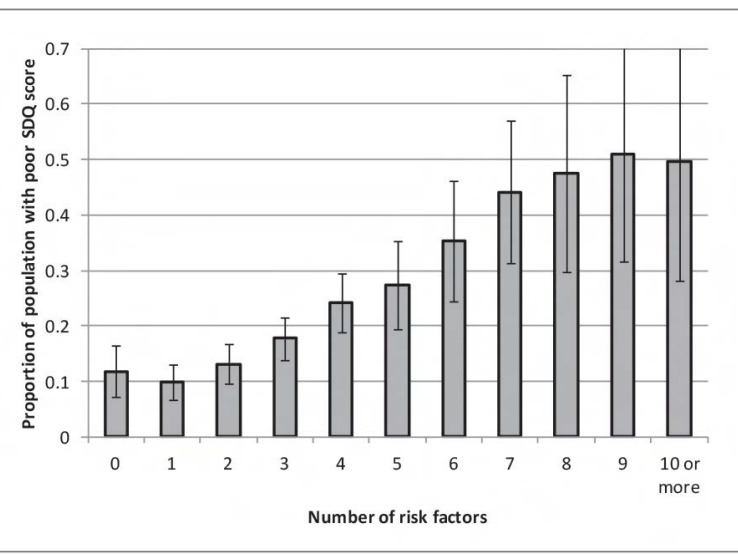

Figure 3d. Poor SDQ ranking

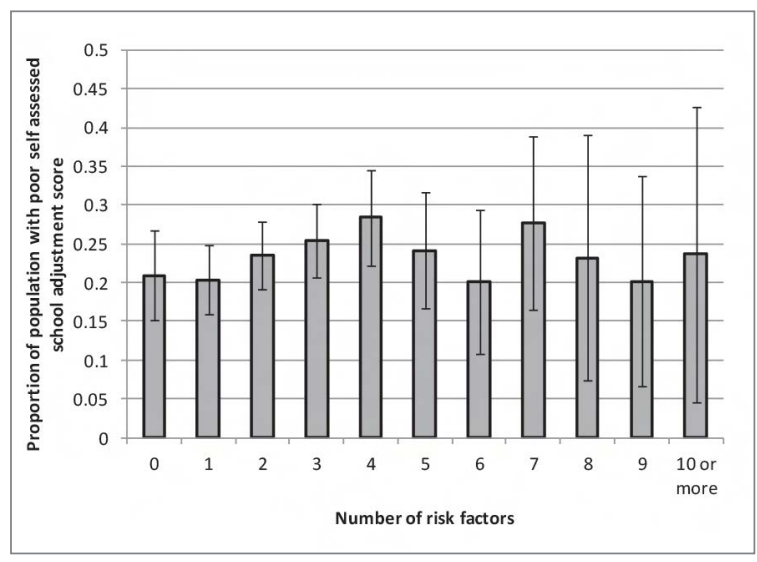

Figure 3e. Poor school adjustment

Source: Customised calculations using Wave 3 and Wave 4 of LSAC.

Figure 3. Proportion of children reported with low outcomes in Wave 4 , by presence of risk factors in Wave 3

Recent Australian research confirms that high-quality teaching is important, showing that children whose teachers had specialist qualifications in early childhood teaching at diploma level and above had better literacy and numeracy test results in Year 3 of school compared to those with certificate-level qualifications in child care or early childhood teaching, or with different types of teaching qualifications (Warren \& Haisken-DeNew, 2013). The data used in our analysis predates the implementation of reforms foreshadowed in the 2008 National Partnership Agreement. For example, the National Quality Framework, established in 2012, encompasses a National Quality Standard, national learning frameworks and a provider assessment and quality rating service, supported by a legal and regulatory framework (ACECQA, 2011). 
Table 4. Effect of explanatory variables on the probability of poor child outcomes, LSAC B cohort (excluding children attending full-time school in Wave 3), Wave 4

\begin{tabular}{|c|c|c|c|c|c|}
\hline Explanatory variables & $\begin{array}{l}\text { Low } \\
\text { achievement }\end{array}$ & Low maths & Low literacy & $\begin{array}{l}\text { Poor SDQ } \\
\text { ranking }\end{array}$ & $\begin{array}{l}\text { Poor school } \\
\text { adjustment }\end{array}$ \\
\hline Study child is male & $0.034 * * *$ & $0.045 * * *$ & $0.053 * * *$ & $0.023 * * *$ & $0.156 * * *$ \\
\hline Age of study child (months) & -0.001 & $-0.007 * * *$ & $-0.004 * * *$ & -0.001 & 0.000 \\
\hline Attended one to 10 hours of preschool & 0.000 & 0.008 & 0.003 & 0.008 & -0.001 \\
\hline Attended 10 to 19 hours of preschool & 0.004 & 0.001 & 0.008 & 0.012 & 0.013 \\
\hline Attended 20 or more hours of preschool & 0.012 & -0.025 & 0.001 & 0.030 & $0.063 * *$ \\
\hline $\begin{array}{l}\text { Attended one to } 10 \text { hours of day care } \\
\text { without preschool program }\end{array}$ & -0.009 & 0.006 & -0.001 & 0.000 & 0.009 \\
\hline $\begin{array}{l}\text { Attended } 10 \text { to } 19 \text { hours of day care } \\
\text { without preschool program }\end{array}$ & 0.004 & 0.010 & -0.003 & 0.019 & 0.035 \\
\hline $\begin{array}{l}\text { Attended } 20 \text { or more hours of day care } \\
\text { without preschool program }\end{array}$ & $0.029 *$ & 0.031 & 0.022 & $0.028 *$ & 0.030 \\
\hline Poverty & $0.020 *$ & $0.049 * * *$ & $0.020 * *$ & 0.008 & 0.018 \\
\hline Housing instability & $-0.024 * *$ & $0.046 * *$ & -0.005 & $0.037 * *$ & 0.009 \\
\hline Housing stress & 0.021 & 0.025 & -0.007 & 0.024 & $0.081 * *$ \\
\hline Competition for parenting time & 0.010 & 0.003 & $0.021 * *$ & -0.009 & -0.003 \\
\hline Neighbourhood disadvantage & $0.029 * *$ & 0.006 & 0.007 & $0.019 *$ & -0.018 \\
\hline Low accessibility & -0.011 & 0.008 & -0.005 & $0.015 *$ & 0.023 \\
\hline Difficult temperament & $0.037 * *$ & 0.015 & 0.021 & $0.182 * * *$ & 0.015 \\
\hline Biomedical risk factors & $0.065 * * *$ & $0.048 * * *$ & $0.040 * * *$ & $0.042 * * *$ & -0.008 \\
\hline Early childhood risk factors & 0.004 & $0.024 * *$ & 0.009 & $0.020 * *$ & -0.016 \\
\hline High TV watching & 0.020 & 0.001 & 0.005 & $0.029 * *$ & 0.008 \\
\hline Sole parent & -0.011 & -0.018 & -0.010 & 0.021 & $0.127 * * *$ \\
\hline Low other parent employment & -0.003 & -0.020 & 0.001 & 0.026 & 0.025 \\
\hline Low primary carer employment & 0.006 & 0.010 & 0.009 & 0.008 & $-0.020 *$ \\
\hline High primary carer employment & $0.033 * *$ & $0.030 *$ & 0.021 & -0.009 & -0.005 \\
\hline Teenage mother & $0.070 * *$ & 0.028 & 0.017 & $0.093 * *$ & -0.063 \\
\hline Low primary carer education & $0.048 * * *$ & 0.018 & $0.025 * * *$ & $0.021 * *$ & 0.011 \\
\hline Potential language difficulties & 0.007 & -0.015 & 0.008 & 0.010 & $-0.049 * * *$ \\
\hline Parental psychological distress & -0.002 & 0.002 & -0.009 & $0.049 * * *$ & -0.020 \\
\hline Primary carer or other parent in poor health & 0.016 & 0.007 & 0.007 & $0.020 *$ & -0.012 \\
\hline Indigenous child & $0.037 *$ & -0.017 & 0.024 & 0.013 & 0.018 \\
\hline Poor parenting skills & $0.018 * *$ & 0.010 & 0.003 & $0.050 * * *$ & $0.029 *$ \\
\hline Low reading & 0.014 & $0.043 * * *$ & $0.028 * * *$ & 0.009 & 0.016 \\
\hline Parental conflict & -0.001 & -0.010 & $-0.006 * *$ & $0.026 * *$ & $0.035 * *$ \\
\hline Parental substance use & -0.004 & -0.015 & -0.003 & -0.022 & -0.003 \\
\hline Parental instability & $0.053 * *$ & -0.024 & 0.055 & -0.005 & -0.042 \\
\hline Probability of the base case & 0.041 & 0.062 & 0.039 & 0.050 & 0.110 \\
\hline Pseudo R-squared & 0.0937 & 0.0650 & 0.0791 & 0.1202 & 0.0616 \\
\hline Number of observations & 2109 & 2077 & 2112 & 2575 & 2563 \\
\hline
\end{tabular}

Note: The base case individual is female, 57 months old, has none of the included risk factors and did not attend preschool or day care Variables for which the coefficient is statistically significant at the 1 per cent level of significance are labelled ***; those statistically significant at the 5 per cent level of significance only are labelled **; and those statistically significant at the 10 per cent level of significance only are labelled *.

Source: Customised calculations using Wave 3 and Wave 4 of LSAC. 
At the time of writing in early 2016, the government's response to recommendations from the Productivity Commission's Inquiry into Child Care and Early Childhood Learning (PC, 2014) included the Child Care Safety Net, aimed at improving accessibility for 'disadvantaged communities and vulnerable and at-risk children and their families' (Department of Education and Training, 2015). Initiatives to increase access for at-risk children are welcome, as our results confirm previous findings that these children are less likely to participate in preschool or day care (Baxter \& Hand, 2013).

However, our analysis also shows that at the time of LSAC Wave 3 (2008), children's risk burden on entry to preschool and day care was the main driver of their academic, social and emotional and school adjustment outcomes in the early school years, measured by LSAC in Wave 4 (2010), and this association was not moderated by their prior attendance at preschool programs or day care services. These results serve as a benchmark for future evaluation of recent policy initiatives aimed at improving access to, and quality of, these services

\section{Endnotes}

Funding for the analysis presented in this paper was provided by Goodstart Early Learning, who also provided comments on an earlier draft of the paper. However, the opinions expressed in the paper should be attributed to the authors.

\section{References}

Australian Children's Education and Care Quality Authority (ACECQA). (2011). National Quality Framework. Retrieved 20 December, 2015, from www.acecqa.gov.au/nationalquality-framework

Australian Government. (2015). Findings from the AEDC. Retrieved 8 August, 2016, from www.aedc.gov.au/parents/ findings-from-the-aedc.

Australian Institute of Family Studies (AIFS). (2014). The Longitudinal Study of Australian Children: Annual Statistical Report 2013. Melbourne, Vic.: AlFS.

Australian Institute of Family Studies (AIFS). (2015). Longitudinal Study of Australian Children Data User Guide-November 2015. Melbourne, Vic.: AIFS.

Australian Institute of Family Studies (AIFS). (2016). Wave 6 release labelled study questionnaires. Retrieved from WWW.growingupinaustralia.gov.au/studyqns/wave6qns/ Isaclabelledquestionnairesw6.pdf.

Baxter, J., \& Hand, K. (2013). Access to early childhood education in Australia (research report no. 24). Melbourne, Vic.: Australian Institute of Family Studies.

Blake, K. S., Kellerson, R. L., \& Simic, A. (2007). Measuring overcrowding in housing. Washington, DC: Department of Housing and Urban Development, Office of Policy Development and Research.
Bowes, J., Wise, S., Harrison, L., Sanson, A., Ungerer, J., Watson, J., \& Simpson, T. (2003). Continuity of care in the early years?: Multiple and changeable care arrangements. Family Matters, 64, 30-35.

Bowes, J. M., Harrison, L., Ungerer, J., Simpson, T., Wise, S., Sanson, A., \& Watson, J. (2004). Child care choices: A longitudinal study of children, families and child care in partnership with policy makers. The Australian Educational Researcher, 31(3), 69-86.

Bowes, J., Harrison, L., Sweller, N., Taylor, A., \& NeilsenHewett, C. (2009). From child care to school: Influences on children's adjustment and achievement in the year before school and the first year of school. Sydney, NSW: NSW Department of Community Services.

Coley, R. L., \& Lombardi, C. M. (2012). Dynamics of early maternal employment in low-income families. In A. Kalil, P. Brandon \& R. Haskins (Eds.), Investing in children: Work, education, and social policy in two rich countries (pp. 24-47). Washington, DC: Brookings Institution.

Council of Australian Governments (COAG). (2009). National Partnership for Early Childhood Education. Canberra, ACT: COAG.

Department of Education and Training. (2015). Jobs for Families Child Care Package. Retrieved 8 January, 2016. from www.education.gov.au/jobsforfamilies.

Elliott, A. (2006). Early childhood education: Pathways to quality and equity for all children. Sydney, NSW: Australian Council for Educational Research.

Fergusson, D. M., \& Horwood, L. J. (2003). Resilience to childhood adversity: Results of a 21 year study. In S. S. Luthar (Ed.), Resilience and vulnerability: Adaptation in the context of childhood adversities (pp. 130-155). Cambridge, UK: Cambridge University Press.

Goodman, R. (1997). The Strengths and Difficulties Questionnaire: A research note. Journal of Child Psychology and Psychiatry, 38(5), 581-586.

Gray, M., \& Baxter, J. (2012). Family joblessness and child wellbeing in Australia. In A. Kalil, P. Brandon \& R. Haskins (Eds.), Investing in children: Work, education, and social policy in two rich countries (pp. 48-78). Washington, DC: Brookings Institution.

Greene, W. H. (2003). Econometric analysis (5th ed.). Upper Saddle River, NJ: Pearson Education.

Harrison, L. J., Goldfeld, S., Metcalfe, E., \& Moore, T. (2012). Early learning programs that promote children's developmental and educational outcomes. Resource sheet no. 15. Produced for the Closing the Gap Clearinghouse. Canberra, ACT/Melbourne, Vic.: Australian Institute of Health and Welfare/Australian Institute of Family Studies.

Hayes, A., Weston, R., Qu, L., \& Gray, M. (2010). Families then and now: 1980-2010 (Fact sheet). Melbourne, Vic.: Australian Institute of Family Studies.

Heckman, J. J. (2013). Giving kids a fair chance. Cambridge, MA: MIT Press.

Kalil, A. (2009). Joblessness, family relations and children's development. Family Matters, 83, 15-22.

Koenen, K., Moffitt, T., Caspi, A., Taylor, A., \& Purcell, S. (2003). Domestic violence is associated with environmental suppression of IQ in young children. Development \& Psychopathology, 15(2), 297-311.

Lewis, J. (2006). How does security of tenure impact on public housing tenants? Australian Housing and Urban Research Institute Research and Policy Bulletin, 78, 1-6.

Linver, M. R., Brooks-Gunn, J., \& Kohen, D. E. (2002). Family processes as pathways from income to young children's development. Developmental Psychology, 38(5), 719-734. 
Lupien, S. J., McEwen, B. S., Gunnar, M. R., \& Heim, C. (2009). Effects of stress throughout the lifespan on the brain, behaviour and cognition. Nature Reviews Neuroscience, 10(6), 434-445.

Magnuson, K. A., Ruhm, C., \& Waldfogel, J. (2007). Does prekindergarten improve school preparation and performance? Economics of Education Review, 26(1), 33-51.

Mallik, S., \& Spiker, D. (2004). Effective early intervention programs for low birth weight premature infants: Review of the Infant Health and Development Program (IHDP). In R. E. Tremblay, R. G. Barr \& R. Peters (Eds.), Encyclopedia on Early Childhood Development [online] (pp. 1-9). Montreal, Canada: Centre of Excellence for Early Childhood Development. Retrieved from www.child-encyclopedia. $\mathrm{com} /$ sites/default/files/textes-experts/en/809/effective-earlyintervention-programs-for-low-birth-weight-premature-infantsreview-of-the-infant-health-and-development-program-ihdp.pdf.

Oberklaid, F., Baird, G., Blair, M., Melhuish, E., \& Hall, D. (2013). Children's health and development: Approaches to early identification and intervention. Archives of disease in childhood, 98(12), 1008-1011.

Pettit, G. S., Bates, J. E., \& Dodge, K. A. (1997). Supportive parenting, ecological context, and children's adjustment: A seven year longitudinal study. Child development, 68(5), 908-923.

Pordes Bowers, A., Strelitz, J., Allen, J., \& Donkin, A. (2012). An equal start: Improving outcomes in children's centres. The Evidence Review. London, UK: University College London Institute of Health Equity.

PricewaterhouseCoopers (PwC). (2012). A practical vision for early childhood education and care. Melbourne, Vic.: PwC.

Productivity Commission (PC). (2014). Childcare and Early Childhood Learning: Productivity Commission Inquiry Report, No. 73 (Vol. 2). Canberra, ACT: PC.

Rothman, S. (2009). The development and use of educational measures in the Longitudinal Study of Australian Children. Paper presented at the 2nd Longitudinal Study of Australian Children (LSAC) Research Conference, Melbourne, Victoria.

Sameroff, A. J. (1998). Environmental risk factors in infancy. Pediatrics, 102(5 Supplement E1), 1287-1292.

Sanson, A., Nicholson, J., Ungerer, J., Zubrick, S., Wilson, K., Ainley, J., ... Sawyer, M. (2002). Introducing the longitudinal study of Australian children. Melbourne, Vic.: Australian Institute of Family Studies.

Shonkoff, J. P., \& Marshall, P. C. (2000). The biology of developmental vulnerability. In J. P. Shonkoff \& S. J. Meisels (Eds.), Handbook of early childhood intervention (2nd ed., pp. 35-53). Cambridge, UK: Cambridge University Press.

Shonkoff, J. P., Richter, L., van der Gaag, J., \& Bhutta, Z. A. (2012). An integrated scientific framework for child survival and early childhood development. Pediatrics, 129(2), e460-e472.

Smart, D., Sanson, A., Baxter, J., Edwards, B., \& Hayes, A. (2008). Home-to-school transitions for financially disadvantaged children. Sydney, NSW: The Smith Family.

Soloff, C., Lawrence, D., \& Johnstone, R. (2005). LSAC technical reference paper number 1: Sample design. Melbourne, Vic.: Australian Institute of Family Studies.

Taylor, M., \& Edwards, B. (2012). Housing and children's wellbeing and development: Evidence from a national longitudinal study. Family Matters, 91, 47-61.

Urbis Social Policy. (2011). Evaluation of the National Partnership Agreement in Early Childhood Education: Annual Progress Report 2010. Canberra, ACT: Department of Education, Employment and Workplace Relations.
Wake, M., Sanson, A., Berthelsen, D., Hardy, P., Mission, S., Smith, K., \& Ungerer, J. (2008). How well are Australian infants and children aged 4 to 5 years doing? Findings from the Longitudinal Study of Australian Children Wave 1. Social Policy Research Paper No. 36. Canberra, ACT: Department of Families, Housing, Community services and Indigenous Affairs.

Warren, D., \& Haisken-DeNew, J. P. (2013). Early bird catches the worm: The causal impact of pre-school participation and teacher qualifications on Year 3 National NAPLAN Cognitive Tests. Melbourne, Vic.: Melbourne Institute of Applied Social and Economic Research.

Zubrick, S. R., Taylor, C. L., \& Christensen, D. (2015). Patterns and predictors of language and literacy abilities 4-10 Years in the Longitudinal Study of Australian Children. PLOS ONE, 10(9), 1-29. doi: 10.1371/journal.pone.0135612

Zyngier, D. (2012). New reports sound alarm on school performance: Experts respond. The Conversation [online]. Retrieved 5 May, 2015, from https://theconversation.com/new-reports-sound-alarmon-school-performance-experts-respond-11298. 